\title{
Social Participation in Management Councils of Protected Areas: Normative advances and the perspective of ICMBio Environmental officers
}

\author{
Deborah Santos Prado \\ Luciana Gomes de Araujo \\ Paula Chamy \\ Ana Carolina Esteves Dias \\ Cristiana Simão Seixas
}

${ }^{I}$ Center for Environmental Studies and Research, University of Campinas, Campinas, São Paulo, Brazil.

${ }^{\text {II }}$ Center for Environmental Studies and Research, University of Campinas, Campinas, São Paulo, Brazil and Institute of Energy and Environment, University of São Paulo, São Paulo, Brazil.

${ }^{\text {III }}$ Center for Environmental Studies and Research, University of Campinas, Campinas, São Paulo, Brazil.

Iv Biology Institute, University of Campinas, Campinas, São Paulo, Brazil and School of Environment, Resources and Sustainability. Faculty of Environment. University of Waterloo, Canada.
${ }^{V}$ Center for Environmental Studies and Research, University of Campinas, Campinas, São Paulo, Brazil.

\begin{abstract}
Management councils of Protected Areas are an important tool to the exercise of social participation of individuals and groups struggling for social-environmental causes in Brazil's democracy. This paper aims to integrate the main regulations guiding the social participation in Management Councils of Protected Areas in Brazil and the perception of managers and technicians in order to understand the process of elaboration of the rules, the behind the scenes, and negotiations. Our findings highlight that social participation has been formally ensured in many aspects, revealing democratic advancements in the field of Protected Areas management in Brazil. However, despite remarkable progress, many challenges remain, including aspects of representation, independency, level of influence, and sharing power in decision-making processes. The outcomes of participation are ongoing processes of learning and negotiation, which are reflected in the improvement of the legal arrangements analyzed.
\end{abstract}

Keywords: Participatory Management; Representativeness; Environmental Policy; Consultative Council; Deliberative Council.

São Paulo. Vol. 23, 2020

Original Article

DOI: http://dx.doi.org/10.1590/1809-4422asoc20180036r2vu2020L5AO 


\section{Introduction}

The creation of instruments related to social participation in Brazil has contradicted statements in the international literature over the past decades, according to which features of institutions and standards of political initiatives of Latin-American social actors would prevent the existence of inclusive arenas representing societal interests (CÔRTES, 2007). At the end of the 1970s, with the process of Brazilian redemocratization, the theme of public or popular participation guided the demands of protests and mobilizations of several social movements. As a result of this commotion, the establishment of Management Councils represented one of the most important institutional innovations of public policies of the country in the second half of the 1980s (GOHN, 2011).

Management Councils hold public forums for gathering citizen demands, conduct specific interest pacts of several social groups, and aim to expand the guarantee for social participation of groups with restricted access to the State apparatus (LUCHMANN; BORBA, 2008). They constitute a public space where individuals interact, debate, and present demands on strategic issues, making the public authority sensitive to their deliberations (AVRITZER, 2000).

The Councils are provided for in the 1988 Constitution, as well as in other laws, as instruments for the expression, representation, and participation of the population (JACOBI; BARBI, 2007; GOHN, 2011), and play the role of mediating the relationship between civil society and the State (AVRITZER, 2000) in the field of public planning (VAZ, 2011). As examples of these forums in the Brazilian socio-environmental sphere, we can mention the Environmental Councils (National, State, and Municipal), the Hydrographic Basin Committees, and the Councils of Protected Areas.

The evaluation of participatory experiences has often been negative, due to the criticism of their participatory procedures for the consolidation of democratic instruments. Dagnino (2002) suggests we should be careful when evaluating these processes. According to the author, a more productive evaluation, from a political point of view, should start from the recognition of the complexity of these processes and the diversity of contexts, involving multiple relations between heterogeneous political forces. It is worth highlighting that the discussion and debates about the desirable (and possible) democracy are current and have been going through a winding path crossed by disputes over the meanings of participation (LUCHMANN, 2006). Such disputes should also be analyzed within the context of the creation of formal institutions that regulate the operationalization of these Councils.

Since institutional designs are not ideologically neutral, and their specificities are directly focused on participatory results (FARIA; RIBEIRO, 2011), to know the actors involved in the process of formulating these arrangements is paramount for understanding the critical points and negotiations that take place on the sidelines. When not interpreted in a reductionist way, elements that constitute the rules of Councils, and which shape their institutional design, serve as a guide for the evaluation of weaknesses and possibilities of the effective social participation in these management instruments (FARIA; RIBEIRO, 2011). 
Considering all this and focusing on Management Councils of Protected Areas in Brazil, we aim to present the evolution of guidelines and criteria of social participation included in the legal frameworks of Protected Areas' Councils, including the perspective of environmental officers involved in processes for formulating these legal arrangements. We seek to understand, in addition to the final institutional design, the context of the behind the scenes initiatives for formulating the analyzed rules, and specifically the context of disputes and negotiations between actors involved in these processes. Moreover, we aim to discuss the main changes in factors that affect the effective exercise of social participation and control and key elements for creating democratic spaces and spaces for social inclusion in protected areas.

\section{Research Methods}

To analyze the legal regulatory frameworks of Management Councils of Protected Areas (PA's) at the federal level, we surveyed the main regulations formulated on the matter (Table 1). The analysis of regulations was based on criteria for evaluating public participation proposed by Rowe and Frewer (2000), who aimed at verifying the effectiveness of citizens' participation in environmental- and risk-related management procedures. These criteria are divided into two subsets, namely acceptance criteria, which are related to the creation and implementation of participation processes, and process criteria, which are related to the reality of public engagement and the practical potential of these processes (ROWE; FREWER, 2000). In this article, we chose to analyze the acceptance criteria, which are comprised of aspects of representativeness, independence, early involvement of participants, ability to influence policies, and process transparency.

Acceptance criteria were chosen because they can be used without monitoring participatory processes in loco. As an exception, the criterion of structured decision-making (which is part of the process criteria) was also included in the analyses, since we understand it as an aspect present in legal documents, which therefore can be evaluated (see the definition of the criteria and their implementation in Table 2 of our article, in ROWE; FREWER, 2000 and TRIMBLE et al. 2014).

Table 1. Regulatory rules of Management Councils of PAs, their objectives, and the position held by officers interviewed at the time of formulating the rules (in some cases, the same officer participated in more than one formulation process, occupying different positions and separately granting information on each regulation).

\begin{tabular}{c|c|c}
\hline Rules & Objectives & Interviewees - Officers \\
\hline $\begin{array}{c}\text { FEDERAL LAW } \\
\text { no. 9,985/2000 }\end{array}$ & $\begin{array}{c}\text { Establishes the Brazilian System of Conserva- } \\
\text { tion Units - SNUC and provides for other } \\
\text { measures. }\end{array}$ & - \\
\hline
\end{tabular}




\begin{tabular}{|c|c|c|}
\hline $\begin{array}{c}\text { FEDERAL DECREE } \\
\text { no. } 4,340 / 2002\end{array}$ & Regulates articles of Federal Law no. 9,985/2000. & - \\
\hline $\begin{array}{l}\text { NORMATIVE } \\
\text { INSTRUCTION } \\
\text { no. 02/ICMBio - } \\
09 / 18 / 2007 *\end{array}$ & $\begin{array}{l}\text { Regulates the guidelines, rules, and procedures } \\
\text { for the establishment and operationalization of } \\
\text { the Deliberative Council of Extractive Reserves } \\
\text { and Sustainable Development Reserves. }\end{array}$ & $\begin{array}{l}\text { - Coordination of Extractive Reserves } \\
\text { (CGREX/Socio-environmental Board/ } \\
\text { IBAMA - (Brazilian Institute of En- } \\
\text { vironment and Renewable Natural } \\
\text { Resources); } \\
\text { - National Center for Traditional } \\
\text { People and Sustainable Development } \\
\text { (CNPT/IBAMA) } \\
\text { - Environmental Education Center/ } \\
\text { IBAMA }\end{array}$ \\
\hline $\begin{array}{l}\text { NORMATIVE } \\
\text { INSTRUCTION } \\
\text { no. } 11 / \text { ICMBio - } \\
06 / 08 / 2010 *\end{array}$ & $\begin{array}{l}\text { Regulates the guidelines, rules, and procedures } \\
\text { for the establishment and operationalization of } \\
\text { Consultative Councils in Federal PAs. }\end{array}$ & $\begin{array}{l}\text { - General Coordinator of Socio-envi- } \\
\text { ronmental Management } \\
\text { - Environmental Analyst of the Board } \\
\text { of Conservation Units for Sustainable } \\
\text { Use and Traditional Populations }\end{array}$ \\
\hline $\begin{array}{c}\text { NORMATIVE } \\
\text { INSTRUCTION } \\
\text { no. 09/ICMBio - } \\
12 / 05 / 2014\end{array}$ & $\begin{array}{l}\text { Regulates the guidelines, rules, and procedures } \\
\text { for the establishment, implementation, and } \\
\text { amendment of the structure of Management } \\
\text { Councils of Federal PAs. }\end{array}$ & $\begin{array}{l}\text { - Coordination of Participatory Man- } \\
\text { agement; } \\
\text { - National Center for research and } \\
\text { conservation of socio-biodiversity } \\
\text { associated with traditional people } \\
\text { (CNPT/ICMBio) }\end{array}$ \\
\hline $\begin{array}{l}\text { ORDINANCE } \\
\text { No. 48/ICMBio - } \\
\text { 05/17/2016 }\end{array}$ & $\begin{array}{l}\text { Provides for the procedures regarding support to } \\
\text { the Management Councils of Federal CUs, their } \\
\text { integration into ICMBio, and responses to peti- } \\
\text { tions approved by them. }\end{array}$ & $\begin{array}{l}\text { - General Coordination of Socio- } \\
\text { environmental Management }\end{array}$ \\
\hline
\end{tabular}

* NI (Normative Instruction) repealed after approval of NI no. 09, of 2014. They are included in the analysis for understanding the evolution of participative elements in the regulations over the years. Source: Prepared by the authors.

Criteria of public participation were qualitatively evaluated, based on an intended reference of real participation, which in our case is the one described in the analyzed legislations. The interpretation of how the criteria for evaluating public participation was made to meet the objectives of the analysis is described in Table 2.

For understanding the internal debate carried out in the environmental body (currently the Chico Mendes Institute for Biodiversity Protection - ICMBio) responsible for formulating the analyzed normative instructions (i.e., an administrative act, that may supplement a policy in its administration), 13 environmental officers involved in the establishment of one or more normative instructions (NIs), which are addressed in this analysis, were invited to participate in an interview. ICMBio officers were identified using snowball sampling (BERNARD, 2006). We tried up to three times to schedule the interview, by telephone and/or e-mail, receiving responses and acceptances from 6 environmental officers. Semi-structured interviews were conducted in 2016, in person, with 2 officers and via Skype with 2 others. The same questions and interview script were 
sent, as a questionnaire, via e-mail to the others.

The Informed Consent Form was presented to all interviewees, who agreed upon all terms and conditions. The three forms of interaction with interviewees varied due to logistic difficulties in accessing the interviewees, although they did not present methodological limitations. To preserve the identity of the interviewees, their narratives are referenced with random numbers preceded by the "EO" code (standing for "Environmental officer").

Topics addressed in the interviews included (i) the administrative and political context in which the rule was formulated, (ii) the rule formulation process, (iii) challenges of the process, and (iv) advancements towards public participation identified by the interviewees. The qualitative analysis of data on the interviews included the identification of emerging themes, the codification (BERNARD, 2006) of information related to each of the Rowe and Frewer's criteria (2000), and the triangulation of data (BERNARD, 2006) by the cross-referencing of data on interviews and the content of the rules.

\section{The political context for formulating new regulations}

The Brazilian System of Conservation Units (SNUC - Federal Law 9,985/2000) represents a very important legal advancement for the regulation of types and rules of federal, state, and municipal Protected Areas ${ }^{1}$. The political negotiation that culminated in the approval of the SNUC lasted for more than 10 years, and it reveals, among other aspects, by the divergence between preservationists and socio-environmentalists ${ }^{2}$ regarding their treatment given to traditional populations and the population's participation in the process of creation and management of PAs (MEDEIROS, 2006; BENSUSAN, 2014; RAMOS, 2014).

Since SNUC was established, the Deliberative and Consultative Management Councils became part of the management of PAs. On the one hand, the Deliberative Councils of Extractive Reserves (RESEX) and the Sustainable Development Reserves (RDS) were established, with power to deliberate issues related to the management of PAs and to propose resolutions. On the other hand, the Consultative Councils were established with powers to advise and issue statements, recommendations, and motions.

The establishment of Management Councils in PAs brought the need for greater normative details about the rules for the operation of Councils. The NI 02/2007, specific to Extractive Reserves (RESEX) and Sustainable Development Reserves (RDS) ${ }^{3}$, was the first regulation of the Management Councils after the approval of the SNUC. It was formulated with the participation of civil society, especially of community leaders,

1 - Protected Areas in Brazil are named as Conservation Units following the Brazilian National System of Conservation Units. The Conservation Units can be classified in two broad groups: Full Protection (no-take areas) and Sustainable Use (multiple uses).

2 - The dichotomy between preservationists and socio-environmentalists is based on the understanding about the society-nature relationship. To deepen this debate, see Diegues (1996); Arruda (1999) and Santili (2005).

3 - Both types of protected areas are classified as IUCN category VI (protected area with sustainable use of natural resources), where the main users are traditional populations. 
beneficiaries of RESEX, and IBAMA ${ }^{4}$ officers (from CNPT and the Socio-environmental Board at the time).

With the creation of ICMBio in 2007, the Coordination of Socio-environmental Management became responsible for implementing the two types of Councils, while still operating under the organizational logic of the division between no-take Protected Areas and Sustainable Use Protected Areas5. "At the time, there was guidance on how to structure the Consultative Council, but there was no NI, and we had just created the NIs for RESEX" (EA5). It was only in 2010, from the adaptation of NI no. 02, of 2007, that the first NI for regulating Consultative Councils was published (NI ICMBio no. 11, of 2010).

According to the interviewees, the political context of ICMBio in subsequent years pointed to initiatives for eliminating "divisions existing in the discussion involving Sustainable Use PAs and no-take PAs, reflecting on the uniformity (when possible) of guidelines for the establishment and implementation of management instruments for both groups" (EA1). Based on this context, the elaboration of NI 09/2014 began, as illustrated by one of the interviewees:

"[...] I always say that we have the ICMBio and the Chico Mendes Institute. Both sides within the same institution deemed there was some kind of schizophrenia in the body. We had a President with a socio-environmental profile and a Director with an ultra-radical profile as for the preservationist field. So, the context wasn't very favorable. And we were counting on some boldness for unifying the NIs of no-take PAs and those for Sustainable Use. We were seeking to give a sign for ending this duality, this polarity between the two groups" (EA6).

According to the 2015 ICMBio management report, the creation of Councils was a goal of the strategic planning of the Institute. The percentage of Federal PAs with established Councils has also been an indication of the institutional performance (ICMBio Ordinance no. 53/2016). As mentioned by an officer, the intention was "to secure space" (EA4). By unifying the rules of both types of Councils, three involved environmental officers highlight that NI 09/2014 represented an institutional advancement of ICMBio. Concomitantly with presenting more clarity concerning the jurisdiction and operationalization of the Councils, this NI sought to diminish the separation between the preservationist and socio-environmentalist perspectives written in the regulations of the management instruments provided for in the SNUC.

4- Brazilian Institute of Environment and Renewable Natural Resources, federal environmental agency in charge of PAs until 2007.

5 - Board of no-take Protected Areas (Diretoria de Unidades de Conservação de Proteção Integral - DIREP) and Board of Sustainable Use Protected Areas (Diretoria de Unidades de Conservação de Uso Sustentável - DIUSP). 


\section{The normative evolution of Councils of PAs based on criteria for assessing social participation}

From the analysis of the legal instruments regulating the Management Councils (Table 2), we may confirm that NIs are in line with what is provided for in the Law and the Decree regulating the SNUC. Regulations formulated until 2014 show an increasing trend towards specifying the structure and operationalization of the Councils. In these documents, mechanisms of participation and representation are reinforced such as the principle of parity between State and civil society, the representation of the most vulnerable social groups, and the participation of councilors in the establishment of the structure and bylaw of the Councils.

The conducted interviews express the officers' intention as for providing details to confer more procedural clarity to managers. The Council management made efforts to avoid dependence upon the "manager's profile", which is an issue already discussed in several studies (MACEDO et al. 2013, SEIXAS; VIEIRA, 2014; ARAUJO et al. 2017). This provision of details sought, over the years, "to tie minor issues in such a way to provide greater social participation in these spaces and their proper conformation to the local reality" (EA1), and also "to debureaucratize, to make the process simpler, more agile, more dynamic, respecting the very local dynamics [...]" (EA5). The evolution of the rules and their institutional design will be discussed next, based on the criteria for evaluating participation, proposed by Rowe and Frewer (2000) and presented in Table 2. 
Table 2 - Evaluation of the evolution of rules of Management Councils of Protected Areas, according to criteria for evaluating public-participation instruments, proposed by Rowe and Frewer (2000).

\begin{tabular}{|c|c|c|c|c|c|c|}
\hline \multirow{4}{*}{ 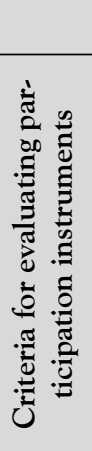 } & \multirow[b]{4}{*}{ Definition } & \multicolumn{5}{|c|}{ Legal Instruments } \\
\hline & & $\begin{array}{l}\text { FEDERAL } \\
\text { LAW }\end{array}$ & FEDERAL DE- & $\begin{array}{l}\text { NORMATIVE IN- } \\
\text { STRUCTION }\end{array}$ & $\begin{array}{l}\text { NORMATIVE IN- } \\
\text { STRUCTION }\end{array}$ & NORMATIVE INSTRUCTION \\
\hline & & $\begin{array}{c}\mathrm{N}^{\circ} 9,985 \\
2000\end{array}$ & $\mathrm{~N}^{\circ} 4.3402002$ & $\begin{array}{c}\mathrm{N}^{\circ} 02 \text { - ICMBio - } \\
\text { 09/18/2007 }\end{array}$ & $\begin{array}{c}\text { N}^{\circ} 11 \text { - ICMBio - } \\
\text { 06/08/2010 }\end{array}$ & Nº9 - ICMBio - 12/05/2014 \\
\hline & & $\begin{array}{l}\text { Establishes the } \\
\text { Brazilian System } \\
\text { of Conservation } \\
\text { Units and pro- } \\
\text { vides for other } \\
\text { measures. }\end{array}$ & $\begin{array}{l}\text { Regulates articles of } \\
\text { Law no. } 9,985 \text { of July } \\
18,2000 .\end{array}$ & $\begin{array}{l}\text { Regulates the guidelines, } \\
\text { rules, and procedures for the } \\
\text { establishment and opera- } \\
\text { tionalization of the Delibera- } \\
\text { tive Council of RESEX and } \\
\text { RDS. }\end{array}$ & $\begin{array}{l}\text { Regulates the guidelines, } \\
\text { rules, and procedures for } \\
\text { the establishment and } \\
\text { operationalization of } \\
\text { Consultative Councils in } \\
\text { Federal PAs. }\end{array}$ & $\begin{array}{l}\text { Regulates the guidelines, rules, and } \\
\text { procedures for the establishment, } \\
\text { implementation, and amendment of } \\
\text { the structure of Management Coun- } \\
\text { cils of Federal PAs. }\end{array}$ \\
\hline 造 & $\begin{array}{l}\text { Participants } \\
\text { must constitute } \\
\text { a representative } \\
\text { sample of the } \\
\text { population af- } \\
\text { fected by PAs. }\end{array}$ & $\begin{array}{l}\text { The council } \\
\text { shall consist of } \\
\text { representatives } \\
\text { of public bod- } \\
\text { ies, civil-society } \\
\text { organizations, } \\
\text { and the resident } \\
\text { population. }\end{array}$ & $\begin{array}{l}\text { Details the represen- } \\
\text { tation of civil society } \\
\text { (scientific community } \\
\text { and environmental } \\
\text { NGOs, resident popu- } \\
\text { lation and population } \\
\text { of surrounding areas, } \\
\text { traditional popula- } \\
\text { tion, property owners, } \\
\text { workers, and private } \\
\text { sector); recommends } \\
\text { that representa- } \\
\text { tion must be equal, } \\
\text { considering regional } \\
\text { peculiarities. }\end{array}$ & $\begin{array}{l}\text { Representatives of enti- } \\
\text { ties legally constituted by } \\
\text { traditional populations of } \\
\text { the Unit; representatives of } \\
\text { organizations and individu- } \\
\text { als from traditional popula- } \\
\text { tions of the legitimately } \\
\text { chosen Unit. The majority } \\
\text { of representatives of tradi- } \\
\text { tional populations must be } \\
\text { ensured. }\end{array}$ & $\begin{array}{l}\text { Idem Decree no. } \\
4340 / 2002 \text {. Considers } \\
\text { parity such as the differ- } \\
\text { entiated representation of } \\
\text { several social groups and } \\
\text { the need for promoting } \\
\text { equitable and qualitative } \\
\text { participation of the most } \\
\text { vulnerable social groups. }\end{array}$ & $\begin{array}{l}\text { Reinforces the principle of legitimacy } \\
\text { of representations and the equity of } \\
\text { conditions for the participation of } \\
\text { different sectors of the civil society } \\
\text { and the Public Authority. The struc- } \\
\text { ture, ownership, substitute positions, } \\
\text { parity, and representativeness shall } \\
\text { be defined together with the involved } \\
\text { sectors, considering the reality of } \\
\text { each PA and observing the aspects of } \\
\text { Decree no. } 4340 / 2002 \text {. Guarantees } \\
\text { voting rights to all councilors and } \\
\text { majority representation of traditional } \\
\text { populations in the case of Deliberative } \\
\text { Councils. }\end{array}$ \\
\hline
\end{tabular}




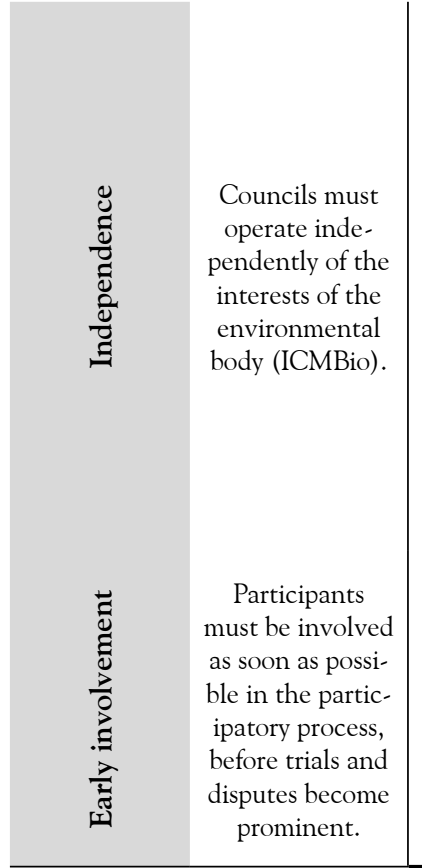

Source: The authors.
Allows for councils to be demanded by traditional populations and ensures participation in all instances,

ICMBio for acknowledgment

Stipulates the formulation of the mulation of the
bylaw, within 90 days, counted from its foundation. with the exception of the

Presidency of the Council, which must be from ICMBio.

Prior to the final approval,

the Bylaws must be forward-

ed to the specific board of purposes and, when necessary, recommendations for amendments shall be given, demonstrating dependence on the executive body.

ICMBio would be in charge of the establishment process as well as of the coordination and presidency. NI enables the creation of thematic groups or chambers for analysis and referral of specificities of the PA.

Indicates the participation of populations since the planning and establishment of Councils, including socioenvironmental diagnosis of

PAs.

Indicates the existence of a Working Group for the establishment process of the Consultative Council from the planning stage to its creation but does not emphasize the participa-
ICMBio would be in charge of the establishment process as well as of the coordination and presidency. NI

enables the creation of Thematic

Chambers and Working Groups (WG) for analysis and referral of specificities of the PAs. Prior to final approval, the Bylaw should also be forwarded to the ICMBio regional office for acknowledgment purposes and, when necessary, recommendations for amend-

ments shall be given. This mechanism should also take place for the entire process of creation and evaluation of action plans of the Councils. tion of local populations at this moment.
Indicates the existence of a WG for the establishment process of the Council from the planning stage to its creation, with representatives of institutions directly involved with PAs and beneficiary populations, when there is any, including the characterization of the territory as one of the activities. 
Table 2 - (cont.) Evaluation of the evolution of rules of Management Councils of Protected Areas, according to criteria for evaluating public-participation instruments, proposed by Rowe and Frewer (2000).

\begin{tabular}{|c|c|c|c|c|c|c|}
\hline \multirow[b]{2}{*}{ 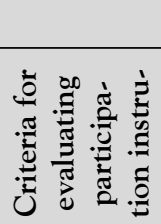 } & \multirow[b]{2}{*}{ Definition } & \multicolumn{5}{|c|}{ Legal Instruments } \\
\hline & & $\begin{array}{c}\text { FEDERAL } \\
\text { LAW } \\
\mathrm{N}^{\circ} 9,985 \\
2000\end{array}$ & $\begin{array}{c}\text { FEDERAL DECREE } \\
\mathrm{N}^{\circ} 4.3402002\end{array}$ & $\begin{array}{l}\text { NORMATIVE IN. } \\
\text { STRUCTION } \\
\text { No } 02 \text { - ICMBio - } \\
\text { 09/18/2007 }\end{array}$ & $\begin{array}{l}\text { NORMATIVE IN } \\
\text { STRUCTION } \\
\text { No }^{\circ} 11 \text { - ICMBio - } \\
06 / 08 / 2010\end{array}$ & $\begin{array}{l}\text { NORMATIVE INSTRUCTION } \\
\text { Nº }^{\circ} \text { - ICMBio - 12/05/2014 }\end{array}$ \\
\hline 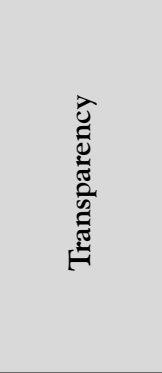 & $\begin{array}{l}\text { The instrument } \\
\text { must ensure } \\
\text { transparency, in } \\
\text { such a way par- } \\
\text { ticipant can be } \\
\text { clearly aware of } \\
\text { the planned and } \\
\text { ongoing processes } \\
\text { and how decisions } \\
\text { are being made. }\end{array}$ & - & $\begin{array}{l}\text { The meeting of the } \\
\text { Council of PAs must } \\
\text { be public, with a pre- } \\
\text { established agenda at } \\
\text { the time of the call } \\
\text { and held in a place of } \\
\text { easy access. }\end{array}$ & $\begin{array}{l}\text { Guidelines for ensuring } \\
\text { information and conditions } \\
\text { for the debate and, when } \\
\text { relevant, specific advisory } \\
\text { services. Administrative } \\
\text { proceedings must be opened } \\
\text { regarding the progress of } \\
\text { the Council in order to } \\
\text { ensure its institutional } \\
\text { memory. }\end{array}$ & $\begin{array}{l}\text { Guidelines to ensure } \\
\text { transparency and social } \\
\text { control in management. } \\
\text { The Council must formal- } \\
\text { ize its guidelines through } \\
\text { recommendations and } \\
\text { motions, which shall be } \\
\text { included in the minutes of } \\
\text { the corresponding meet- } \\
\text { ings. }\end{array}$ & $\begin{array}{l}\text { Guidelines to ensure management } \\
\text { transparency, adequate for the local } \\
\text { reality and participation of different } \\
\text { sectors of the society, including the } \\
\text { promotion of continued training of } \\
\text { the management team and the coun- } \\
\text { cilors. Ensures the public character } \\
\text { of meetings held by the Councils and } \\
\text { disseminates their decisions and state- } \\
\text { ments, through resolutions that shall } \\
\text { be included in the minutes. }\end{array}$ \\
\hline 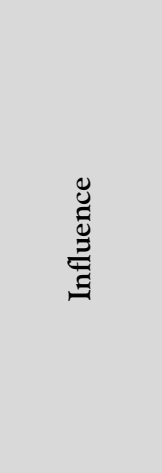 & $\begin{array}{l}\text { Results obtained } \\
\text { from participa- } \\
\text { tion must have a } \\
\text { genuine impact on } \\
\text { management. }\end{array}$ & - & $\begin{array}{l}\text { Jurisdiction to propose } \\
\text { guidelines and actions } \\
\text { to reconcile, integrate, } \\
\text { and optimize the } \\
\text { relationship with the } \\
\text { population surround- } \\
\text { ing or within the PAs; } \\
\text { in addition to monitor- } \\
\text { ing the formulation, } \\
\text { implementation, and } \\
\text { review of the Manage- } \\
\text { ment Plan of PAs. }\end{array}$ & $\begin{array}{l}\text { Jurisdiction to demand } \\
\text { and propose public policies } \\
\text { that promote the quality } \\
\text { of life of traditional popu- } \\
\text { lations of PAs; research } \\
\text { and technologies aimed } \\
\text { at socio-environmental } \\
\text { sustainability, integrating } \\
\text { technical-scientific knowl- } \\
\text { edge and ethnoknowledge; } \\
\text { monitoring the formulation } \\
\text { and implementation of the } \\
\text { Participatory Management } \\
\text { Plan. }\end{array}$ & $\begin{array}{l}\text { Jurisdiction to demand } \\
\text { and propose actions that } \\
\text { promote the conserva- } \\
\text { tion of natural resources } \\
\text { of PAs and socio-envi- } \\
\text { ronmental sustainability, } \\
\text { integrating technical- } \\
\text { scientific knowledge and } \\
\text { traditional knowledge; } \\
\text { environmental education, } \\
\text { monitoring, and manage- } \\
\text { ment of PAs. }\end{array}$ & $\begin{array}{l}\text { Jurisdiction to monitor the formula- } \\
\text { tion and implementation of the Man- } \\
\text { agement Agreement and Participatory } \\
\text { Management Plan (for Deliberative } \\
\text { Councils); demanding and propos- } \\
\text { ing actions directed at conservation, } \\
\text { research, environmental education, } \\
\text { protection, control, monitoring, } \\
\text { and management, in such a way to } \\
\text { promote the conservation of natural } \\
\text { resources of PAs, their buffer zones, or } \\
\text { influence (for both Councils). }\end{array}$ \\
\hline
\end{tabular}




\begin{tabular}{|c|c|c|c|c|c|c|}
\hline 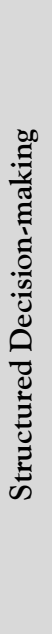 & $\begin{array}{l}\text { The participation } \\
\text { instrument must } \\
\text { provide appropri- } \\
\text { ate mechanisms } \\
\text { for structuring the } \\
\text { decision-making } \\
\text { process. }\end{array}$ & - & $\begin{array}{l}\text { The executing body is } \\
\text { responsible for sup- } \\
\text { porting the councilors' } \\
\text { participation in the } \\
\text { meetings, whenever } \\
\text { requested and duly } \\
\text { justified. }\end{array}$ & $\begin{array}{l}\text { The Council must define } \\
\text { decision-making mecha- } \\
\text { nisms ensuring the effective } \\
\text { participation of traditional } \\
\text { populations in the manage- } \\
\text { ment of PAs and formal- } \\
\text { izing their deliberations } \\
\text { through resolutions signed } \\
\text { by the President of the } \\
\text { Deliberative Council and } \\
\text { supported by minutes. NI } \\
\text { provides for the guarantee } \\
\text { of the right to vote for all } \\
\text { councilors and attaches a } \\
\text { bylaw structuring model. }\end{array}$ & $\begin{array}{l}\text { It is intended to proceed } \\
\text { with the guidelines issued } \\
\text { by the Council. It pro- } \\
\text { vides mechanism for for- } \\
\text { mulating an Action Plan } \\
\text { containing the schedule of } \\
\text { activities and mechanisms } \\
\text { for the annual evaluation } \\
\text { of the Council's activi- } \\
\text { ties. It does not detail the } \\
\text { structure of decision-mak- } \\
\text { ing, but only the need for } \\
\text { formalizing the Council } \\
\text { guidelines through recom- } \\
\text { mendations and motions. }\end{array}$ & $\begin{array}{l}\text { Guidelines to ensure official response } \\
\text { and effective referrals concerning the } \\
\text { statements and deliberations of the } \\
\text { Councils; for Deliberative Councils, } \\
\text { it emphasizes the establishment of } \\
\text { decision-making mechanisms that } \\
\text { ensure the effective participation of } \\
\text { traditional populations in the man- } \\
\text { agement of PAs. For the first time, it } \\
\text { deems as jurisdiction to monitor and } \\
\text { to propose actions for the formulation, } \\
\text { implementation, monitoring, evalu- } \\
\text { ation, and review of management } \\
\text { instruments of PAs. All members of } \\
\text { the Council, including the represen- } \\
\text { tative of ICMBio, must effectively } \\
\text { participate in discussion processes } \\
\text { with voting rights and other forms of } \\
\text { statement. }\end{array}$ \\
\hline
\end{tabular}

Source: The authors. 


\subsection{Representativeness}

Principles on the representativeness of Councils have been historically ensured by formal rules since the Federal Decree 4,340/2002. An important advance of NI $02 / 2007$ is the inclusion of representatives as a non-legal entity, broadening the scope for the participation of individuals and groups of traditional communities represented by selected individuals or leaders. As mentioned by an interviewee, this issue has been the subject of discussions: "How can we ensure representation in places where there were no constituted formal organizations or where they were insufficient to represent all the communities within the RESEX?" (EA1). To some extent, this advancement comprises the social specificities of territories of PAs, often physically isolated and lacking the State social apparatus, as in the case of almost all Amazon PAs.

Moreover, the evolution of the rules reinforces the equitable and qualitative participation of the most vulnerable social groups. In Deliberative Councils, the majority of the board must be represented by traditional populations since NI 02/2007. The majority representation of traditional populations in Deliberative Councils illustrates how changes in the rules are permeated by disputes. One of interviewees mentions that in the NI 02/2007, "some IBAMA managers questioned the competence of this social group in having a majority of representatives in the Council" (EA5). At the end of the formulation process of the normative, there was a common understanding about the importance of guaranteeing simple majority $(50 \%+1)$ to this social group (EA3). In the case of NI 09/2014, the agenda of majority representation in Deliberative Councils posed a challenge once again, especially on the part of the ICMBio federal attorney office: "The attorney was not convinced, by formal aspects, that a NI could assign a majority representation to a social group at the expense of the parity established by Decree 4,340, which regulates the SNUC law" (EA6).

Faced with the concrete threat of withdrawing the majority representation of traditional populations from these Councils, the active role of social movements was imperative. As one interviewee highlights: "We had to join forces with $\mathrm{CNS}^{6}$ and $\mathrm{CON}$ $\operatorname{FREM}^{7}[\ldots]$, we got together with about eight national extractive leaders $[\ldots]$ and we kinda started getting into the Presidency office. Then, he received us [...] it was evident that the ultimate decision was his [president of ICMBio]" (EA6).

Within the formal scope, these results show that despite the technical character permeating the formulation of rules of representativeness within the Councils, the popular and organized pressure of social movements can influence political results, often achieved in upper decision-making level. Still, considering that numerical parity does not necessarily correspond to political parity, it is noteworthy that, in the Councils, the representation of populations affected by the implementation of PAs is indeed ensured only when there are transparency and political commitment, in such a way the themes of interest of involved actors are widely debated and power is shared. Researchers evaluating

6 - Rubber tappers National Council (Conselho Nacional Seringueiro).

7 - National Committee for Strengthening Peoples and Coastal and Marine Extractive Reserves of Brazil (Comissão Nacional para o Fortalecimento dos Povos e Reservas Extrativistas Costeiras e Marinhas do Brasil). 
the operationalization dynamics of PA Councils have noted this same representativeness issue (see TEIXEIRA et al., 2010; CARDOZO et al., 2012; VIVACQUA; RODRIGUES, 2012; NOBRE; SCHIAVETTI, 2013). In the case of the Environmental Protected Area of Baleia Franca, for example, fishers participating in its Council used to deem it as a State space, with the prevalence of State rules and resistance on the part of its agents to share power with local groups (VIVACQUA; RODRIGUES, 2012).

\subsection{Independence}

Some mechanisms identified in the historical analysis of the rules demonstrate, based on the NI no. 11/2010, the increase in possibilities for greater independence in the operationalization of Councils concerning ICMBio interests such as the jurisdiction to create working groups (WGs) and thematic chambers (TCs). WGs and TCs consist of spaces for aligning the execution of actions, negotiation of interests, coproduction of knowledge, independence in decision-making, and social control, constituting decentralizing instruments of action. According to the Guidelines for Councils (Guia de Orientação dos Conselhos), published by ICMBio, WGs and TCs can also "deal with conflicts related to PAs, maturing issues that, when arriving at the Council, can be discussed and forwarded in a more agile manner" (ABIRACHED et al., 2014).

The independence of Councils as decision-makers can be restricted by a control of the ICMBio, both at the local level and hierarchical levels of PAs, including Regional Offices $^{8}$. These latter need, for instance, to be informed or to issue technical opinions on the establishment process of the Councils, their bylaws, amendments to represented sectors, creation of the action plan, and the periodic evaluation of the Councils (NI no. 9/2014, Arts. $8^{\text {th }} ; 10^{\text {th }} ; 24^{\text {th }} ; 26^{\text {th }}$ and $30^{\text {th }}$.

The current role of Regional Offices in relation to Councils results from a decentralization process, according to all interviewees. Previously, the Participatory Management Division, located at the headquarters in Brasília, was in charge of formalizing the Management Councils of PAs throughout Brazil. Since NI no. 09/2014, the understanding was that Regional Offices would have more ownership and knowledge of the "management reality, the territories covered by the PAs, and the analysis and amendment to the structure, which makes a lot of difference in the Council" (EA6).

Although Regional Offices relieve the dependence of PAs on decisions made at the headquarters in Brasília, to achieve this independence, Regional Offices must avoid having an operational character only, but work as a collaborative network of management support (MENDONÇA; TALBOT, 2014), contextualized with the aspirations of councilors at the local level. We understand that the hierarchical control of ICMBio, regulated by legal instruments, represents an independence paradox. On the one hand, this control can enhance compliance with the rules established for the Councils by their managers. 
On the other hand, it can constrain and allow for interests of the environmental body to unilaterally superimpose it's interests for the Councils?.

Changes in the mandate and in government programs, which take place in the alternation of legislatures, are another aspect that interferes with the independence of Councils. In this case, two types of management breaches may occur: the ones caused by allotment of commissioned positions in Regional Offices and superiors of $\mathrm{PAs}^{10}$ and those caused by the high turnover of managers in the team of PAs. For instance, the RESEX of Lago do Capanã Grande (state of Amazonas, Brazil) had at least twelve changes in positions of superiors and technical staff in seven years (ANDRADE, 2014), which interferes with participation processes and consequently with the autonomy of the Management Councils.

\subsection{Early involvement}

The evolution of rules regulating Management Councils reveals an incentive to participants' involvement in the process at earlier stages. The Federal Decree 4,340/2002 regulate the performance of councilors in the formulation of bylaws of the Councils. The NI 2/2007 (Art. $4^{\text {th }}, \S 2$; and Art. $5^{\text {th }}$ ) amends this provision and regulates the participation of representatives of traditional populations in the establishment stage of Deliberative Councils, which remains in the successive NIs.

The provision of details about the formalization of a specific WG for this stage takes place in NI 09/2014, "composed of one or more representatives of the ICMBio, representatives of institutions directly involved with PAs and of traditional beneficiary populations, in case there is any" (NI 9/2014, Art. $9^{\text {th }}$, I). The participants' involvement begins to take place, therefore, not only in the formulation of bylaws after the creation of the Council, but also in the activity for characterizing the territory of PAs and in the mobilization and definition of the sectors of the Public Authority and civil society that will compose it. This innovation is relevant for developing trust among the involved parties, before trials and disputes become prominent (ROWE; FREWER, 2000). At the RESEX of Cassurubá (state of Bahia, Brazil), the development of Fishery Agreements with local fishermen within its Management Council illustrates the efforts required to ensure the involvement of fishermen in this process, partly due to challenges in developing trust between managers and fishermen, which takes place in long-term processes (NOBRE; SCHIAVETTI, 2013).

\footnotetext{
9 - After the extinction of the Regional Offices (Decree $n^{0} 10.234$ of 2020), this discussion could be transferred to the role and performance of the Regional Boards on Management Councils of the PAs, whether in the sense of giving independence to the PAs and their Councils, as well as the possibility of centralized decisions, restricting the independence of the PA. However, the data from this study does not allow us to infer about the role of current Regional Boards. 10 - Complaints can be seen in publications such as Revista Época (10/23/2017); Jornal O eco (10/17/2017); Carta de repúdio ao Loteamento Político de Cargos no ICMBio e IBAMA [Declaration of Repudiation of the Political Allotment of Positions in ICMBio and IBAMA] (ASCEMA, 2017).
} 


\subsection{Transparency}

Overall, NIs have been clarifying the public nature of the Councils. By establishing the need for opening Administrative Proceedings, the NI 02/2007 guaranteed the record of an institutional memory. These formal procedures favor the management transparency. Recording the institutional memory is paramount, considering the turnover of superiors and managers in PAs. Furthermore, it generates information for evaluating management processes of Councils and social learning, and materials are also used as an important data source for research (MAGALHÃES et al., 2010; TEIXEIRA et al., 2010; CARDOZO et al., 2012; NOBRE; SCHIAVETTI, 2013).

NIs 11/2010 and 09/2014 evidenced the need for disseminating recommendations or deliberations of the Councils. Dates and places of meetings must be widely disclosed and in advance to ensure the presence of the largest number of people. The Guidelines for Councils (ABIRACHED et al., 2014) highlights the importance of meeting minutes and attendance list, complementing what is described in NIs.

\subsection{Structured Decision-making}

The analyzed rules discriminate that decision-making in the Councils must ensure representativeness and transparency, but do not explain the structure of the process beyond the prediction of voting and other forms of statements (Art. 29th of NI 9/2014), which must be included in bylaws. Authors of the Guideline for Councils, in turn, mention that decision-making can be consolidated by consensus, by vote, plurality vote, majority vote, or quorum (ABIRACHED et al., 2014, p. 32), but these mechanisms have no normative power and are not detailed as to the procedure.

In NI 11/2010, decisions are expected to be made regarding the formulation and continued evaluation of action plans of the Councils, but without the provision of details. It is only in the NI 9/2014 (Arts. $25^{\text {th }}$ and $26^{\text {th }}$ ) that information on the function of and what should be decided in action plans of PAs is regulated as well as the need for its annual evaluation ${ }^{11}$ and monitoring. No regulations specify the implementation of these management instruments, which may, once again, denote a paradox. On the one hand, they can be flexibly used and be based on the reality and demands of the territory of PAs, resulting in the broadening of councilors' participation. On the other hand, the lack of specific regulation may favor the development and implementation of action plans and top-down evaluations, centrally and/or non-participatory. Power dynamics and the context of local mobilization are imperative for these processes, which are not only guaranteed by de jure instruments. 


\subsection{Influence}

The influence of Councils on the management has been expressed in their jurisdiction since Decree no. 4,340/2002, which was repeated in subsequent NIs. The NI 9/2014, by integrating previous NIs, denominate both Consultative Councils and Deliberative Councils as "Management Councils." Although this term corroborates the 1988 denomination of the Constitution itself, the SNUC does not make this reference. What at first may seem a mere detail of writing, in fact, and once again, expresses the disputes and values of environmental conservation between preservationist and socioenvironmentalist officers, and the role of the Council as an institution for social control. In the words of a civil servant, "sometimes we try to escape a little bit from these dilemmas by saying that SNUC is hybrid. For one, I'd say it's contradictory [...] there's a lot of years of struggle. So, having no 'manager' was nobody's fault. It was intentional, there has been a negotiation" (EA4).

The promotion of public policies for socio-environmental development is still exclusive to the jurisdiction of Deliberative Councils for "demanding and proposing to competent bodies public actions or policies on quality of life and support to extractivism and traditional populations that are beneficiaries of the Conservation Unit" (NI 09/2014, Art. $5^{\text {th }}$ ).

The other jurisdictions, common to both types of Councils, are directly related to conservation policies such as: "demanding and proposing [...] actions directed at conservation, research, environmental education, protection, control, monitoring, and management, in such a way to promote the conservation of natural resources" (Art. $4^{\text {th }}$, III). Although some of the interviewees have mentioned advancements in integrating both types of Councils into a single NI (09/2014), especially to strengthen the Consultative Councils, these are still more limited to their power of influence over PA's management when compared with Deliberative Councils.

The Councils face several challenges in the search for power of influence over the management of the PAs' territories. These challenges are related to the equitable distribution of power among the various interest groups (ARNSTEIN, 1969), access to information, training of councilors and managers (TRIMBLE et al., 2014), recognition and incorporation of different types of knowledge and world views concerning decisions (BORRINI-FEYERABEND et al., 2004, SEIXAS and VIEIRA, 2014), and to a clearer institutional positioning of ICMBio regarding the very power of influence of the Councils. In the words of an environmental officer, "[...] you have a Deliberative Council, it may even decide something. Now, if this will be accepted by the institution is a horse of another color, even though it's Deliberative, it has limitations" (EA2).

The difference between the power of influence of resolutions of Deliberative Councils and recommendations of Consultative Councils may be less expressive when referrals, or responses to resolutions and recommendations, are clearly made. One of the interviewees reported: "[...] I remember the councilors complaining about it, there is no feedback, what is decided doesn't work, it's not implemented. And many people in the institution [ICMBio] get upset about empowering the Council a lot because they believe Councils have been deciding absurd things above the law" (EA2). 
The dilemma about responses and referrals of resolutions and recommendations made by the Councils gave rise to internal discussions within the ICMBio, which culminated in Ordinance 48/2016. We will address this ordinance next, understanding that the assumptions for its formulation, the way it was conducted, and its repeal a few days later dialogues with the aspects of influence, in addition to other criteria previously discussed.

\section{Autonomy of the Councils and the controversial ICMBio Ordinance $48 / 2016$}

Among the controversial points identified in Ordinance 48/2016 was the establishment that any petition of the Councils (statements, motions, recommendations, and resolutions), internal or external, should be submitted to the analysis of higher instances of PAs. Another point also questioned by many officers was the appointment expressed in the Ordinance of Management Councils as "Councils for management support", assuming a secondary role and even contrary to that formulated in the SNUC, in the Federal Decree 4,340/2002 and NI 9/2014.

The conducted interviews clarified the context for the formulation of this Ordinance, which was driven by the ICMBio need for creating an institutional mechanism to respond to the demands or petitions made by the Councils. However, throughout the process, "this began to drift to a debate on: do Councils really have this autonomy to, for instance, from time to time make a motion of repudiation towards a policy of the Presidency?" (EA2). In addition to a context of political instability in 2016 due to the ongoing impeachment process of the government of President Dilma Rousseff, the justification presented for forwarding the Ordinance was that the publication was imperative, as soon as possible, of underway regulations within the body. With limited participation of technicians and formulated in higher offices of ICMBio, the ordinance was published on May 18, 2016.

The repercussion of its publication has immediately mobilized ICMBio environmental officers. In a declaration of repudiation of the National Association of Environmental Officers $^{12}$, changes in the function and autonomy of the Councils, which were included in the Ordinance, were lividly mentioned. After nine days, the Ordinance 48/2016 was repealed (ICMBio Ordinance no. 55, of May 27, 2016). Subsequently, a WG linked to the Coordination of Socio-environmental Management at the time was created to discuss the institutional mechanism for forwarding petitions from the Councils. This WG had the participation of officers with experience in the area, councilors, and researchers.

Two aspects of this process are worth highlighting: (i) the autonomy of Management Councils as a matter of dispute within the environmental body; and (ii) the immediate repercussion of the publication, which culminated in the subsequent repeal of the Ordinance.

As we perceived in the resistance to the majority representation of traditional

12 - Declaration no. 43 AN / 2016. Available from: http://www.ascemanacional.org.br 
populations in Deliberative Councils, the dispute between different trends within ICMBio is not recent. The level of autonomy of the Councils is based, firstly, on the technical understanding between affiliation and subordination. Technically, Councils are linked to ICMBio, since its presidency must be mandatorily assumed by someone from the governing body. On the other hand, as a social-control forum established by the Federal Constitution, Councils should not subordinate all their statements to the formal authorization of the State body. The complexity of the issue brings to light, once again, the paradox of independence, as one interviewee reflects upon:

"Is it [the Council] a mere administrative extension of the PA's man-
agement body or is it an instance with a higher level of autonomy to
the point of forwarding a motion to the Presidency of the Republic,
questioning a hydroelectric power plant in a very important river in
the Amazon? [...] some people defend that statements of the Council
must undergo the scrutiny of the ICMBio Presidency and be distrib-
uted there. Having institutional control over social control" (EA6).

According to Ordinance 48/2016, the restriction of social participation, expressed in the loss of independence of Councils and their power to make decisions and influence the management, weakens the board and reinforces the centralization of decisions at the Institute's headquarters in Brasília. However, it is necessary that "within a porous and pulsating public sphere, topics, positions, and arguments brought by new social actors must find institutional ways for penetrating the State, and hence, for democratizing it, making it the object of citizens' control" (AVRITZER; COSTA, 2004, p.723).

The repeal of the Ordinance resulted from the mobilization of ICMBio officers, not only internally, but also in online forums for discussion and declarations of repudiation. This situation demonstrated there is no consensus on participation levels accepted by the institute, and that part of environmental officers defend the Councils as autonomous instruments of social participation and control. The repeal itself produces elements of institutional learning and accumulation in the debate on social participation.

The analysis of social participation criteria within regulations of the Councils shows us both the existence of factors that guarantee social participation and the permanence of elements that block the effective sharing of power in these spaces. Despite this duality, we must recognize the effort of numerous environmental officers committed to the incorporation of democratic values and guarantees to the rules. We can identify that in some aspects of the regulations, the restraint or control of the exercise of social participation are linked to preservationist conceptions of the management of protected areas. In other cases, we could also verify that limits imposed on social participation and on the autonomy of Councils are related to policies resistant to the democratization of decision-making processes, and to structural characteristics of the operationalization of the State and its techno-bureaucratic logic (DAGNINO, 2002), challenges that are even more serious considering the current political situation of Brazil. 


\section{Final Considerations}

Social participation in Management Councils is guaranteed in several aspects of the rules governing them, which should be considered an achievement in the management of PAs. In practice, we should remember that participation processes are slowly developed and in the long-term (STRINGER et al., 2006; VON KORFF et al., 2010). Although legal rules have evolved to strengthen participation, there are gaps that challenge power asymmetries, weaknesses of independence, influence, decision-making, and representativeness de facto.

The initiative of ICMBio to review its regulations and produce guidelines for councilors and managers can be deemed an achievement in the exercise of participation on the part of the State. The training of managers and councilors and the systematic and continuous evaluation of actions of Councils enrich the guarantee to the effective exercise of social participation.

We stress the importance concerning the analyzed criteria, in such a way they can be considered in the formulation of further rules, including those of a procedural nature such as the quality of access to information, clarity in setting objectives for councilors, and availability of financial resources for implementing more qualified participatory processes.

The analysis of legal instruments allowed us to understand both the maturing of the rule, which seeks to ensure the exercise of social participation in Management Councils, and the paradoxes related to their independence of action and the lack of clarity for their autonomy in collective decision-making processes. Corroborating Gohn (2011), who discusses contradictions inherent in the structure and dynamics of Management Councils, we highlight that despite recognizing these contradictions, Management Councils of PAs represent legitimate and indispensable instruments to create democratic environmental management.

Although regulations of the Councils of PAs are not the only guarantee for the exercise of social participation (and considering that research on the operationalization of councils in loco, with the perception of other involved actors, remains fundamental), they ensure their existence and operationalization as formal arenas for the development of new patterns of interaction between State and society. The effort for Councils not to become mere bureaucratic structures that reinforce social and political inequalities should be made with more State budget priorities towards this purpose, in addition to more openness of this arena for the insertion of distinct values and knowledge in collective actions.

Our results confirm that legal institutional arrangements are not independent products of political ideologies and interests, but rather express the results of correlations of forces, impacting their operationalization dynamics (DAGNINO, 2002). Disputes were evident when attempts to deepen social control and autonomy of the Councils have been threatened. Some examples have demonstrated these disputes such as in the formulation or maintenance of devices that ensure the majority representation of traditional populations in Deliberative Councils, or in an attempt to diminish the role of Councils and subordinate their petitions to the higher levels of ICMBio. Despite the numerous achievements observed in the evolution of regulations, the constant exercise 
of participation and the monitoring of these forums on the part of society remain even more imperative, in such a way to avoid possible setbacks that have already been demonstrated in the current political framework. In our research, we made an innovative effort to present the behind-the-scenes elements, and the perception of environmental analysts involved in the establishment of legal arrangements. Research on the operationalization of Councils at the local level, politically and historically contextualized, including from an institutional-legal point of view, may clarify new advancements or setbacks regarding the participation criteria discussed in this article.

\section{Acknowledgements}

We are grateful for the contributions of the officers of the Chico Mendes Institute for Biodiversity Conservation (ICMBio) who kindly granted us interviews. This study was financed in part by the Coordenação de Aperfeiçoamento de Pessoal de Nível Superior - Brasil (CAPES) (Finance Code 001) and by the São Paulo Research Foundation (FAPESP) (Process № 2015/19439-8). The authors thank Espaço da Escrita - PróReitoria de Pesquisa - UNICAMP - for the language services provided.

\section{References}

ABIRACHED, F.C.M.; LUZ, L.; TALBOT, V.; LASMAR, V. Conselhos Gestores de Unidades de Conservação Federais. Um guia para Conselheiros e Gestores. Instituto Chico Mendes de Conservação da Biodiversidade. 2014.

ANDRADE, R. A. Gestão Participativa de Unidades de Conservação Federais no Sul do Amazonas. In: Bensusan, N.; Prates, A.P. A Diversidade cabe na Unidade? Áreas Protegidas no Brasil. IEB Mil Folhas. p. 683-692. 2015.

ARAUJO, L.G., F. CASTRO, R.R. DE FREITAS, M.A.R.M. VIEIRA e C.S. SEIXAS. Struggles for inclusive development in small-scale fisheries in Paraty, Southeastern Coast of Brazil. Ocean \& Coastal Management, 150: 24-34. 2017.

ARNSTEIN, S.R. A ladder of citizen participation.J.Am. Plann. Assoc., 35: 216-224.1969.

ARRUDA, R. Populações Tradicionais e a proteção dos recursos naturais em unidades de conservação. Ambiente \& Sociedade. n. 5. 1999.

AVRITZER, L. Sociedade civil, esfera pública e poder local: uma análise do orçamento participativo em Belo Horizonte e Porto Alegre. Civil Society and Democratic Governance. 2000.

AVRITZER, L.; COSTA, S. Teoria Crítica, Democracia e Esfera Pública: Concepções e Usos na América Latina. DADOS - Revista de Ciências Sociais, v. 47, n. 4, p. 703-728, 2004. 
BENSUSAN, N. Diversidade e Unidade: Um dilema constante. Uma breve história da ideia de conservar a natureza em áreas protegidas e seus dilemas. In: Bensusan, N.; Prates, A.P.A Diversidade cabe na Unidade? Áreas Protegidas no Brasil. IEB Mil Folhas. 2015.

BERNARD, H. R. Research Methods in Anthropology. Qualitative and Quantitative Approaches. Lanham: Altamira Press. 2006.

BORRINI-FEYERABEND, G.; PIMBERT, M; FARVAR, M. T.; KOTHARI, A; RENARD, Y. Sharing Power. Learning by doing in co-management of natural resources throughout the world. IIED/IUCN/ CEESP/ CMWG, Cenesta, Tehran. 496pp. 2004.

CARDOZO, L. S. et al. Discussões do Conselho Deliberativo da Reserva Extrativista de Canavieiras, Bahia, Brasil: da gestão pesqueira à ambiental. RGCI, Lisboa, v. 12, n. 4, p. 463-475. 2012.

CORTÊS, S.V. Viabilizando a Participação em Conselhos de Política Pública Municipais: arcabouço institucional, organização do movimento popular e policy communities. In: HOCHMAN, G. ARRETCHE, M.; MARQUES, E. (orgs). Políticas Públicas no Brasil. Editora Fiocruz. p.125143. 2007.

DAGNINO, E. 2002. Sociedade Civil, Espaços Públicos e a Construção Democrática no Brasil: Limites e possibilidades. In: Dagnino, E. (org). Sociedade Civil e Espaços Públicos no Brasil. Paz e Terra. 2002.

DIEGUES, Antônio Carlos. O mito moderno da natureza intocada. São Paulo: Hucitec, 1996.

FARIA, C. F; RIBEIRO, U.C. Desenho institucional: Variáveis relevantes e seus efeitos sobre processos participativos. In: Pires, R. R. C. (org). Efetividade das Instituições Participativas no Brasil: Estratégias de Avaliação. Diálogos para o Desenvolvimento. v.7. Instituto de Pesquisa Econômica Aplicada - Ipea, 2011.

GOHN, M.G. Conselhos Gestores e Participação Sociopolítica. Editora Cortez. 4aㅡ edição. 2011.

JACOBI, P. R. e BARBI, F. Democracia e participação na gestão dos recursos hídricos no Brasil. Rev. Katálysis. Florianópolis, 10(2): 237-244. 2007.

LUCHMANN, L.H.H. Os sentidos e desafios da participação. Ciências Sociais Unisinos. 42(1):19-26. 2006.

LUCHMANN, L.H.H.; BORBA, J. Participação, desigualdades e novas institucionalidades: Uma análise a partir de instituições participativas em Santa Catarina. Ciências Sociais Unisinos 44(1):58-68. 2008.

MACEDO, H.S., VIVACQUA, M., RODRIGUES, H.C.L., GERHARDINGER, L.C., Governing wide coastal-marine protected territories: a governance analysis of the Baleia Franca environmental protection area in South Brazil. Marine Policy, 41: 118-125. 2013.

MEDEIROS, R. Evolução das Tipologias e Categorias de Áreas Protegidas no Brasil.Ambiente \& Sociedade. Vol. 9 n. 1. 2006. 
MENDONÇA, F; TALBOT, V. Participação Social na Gestão de Unidades de Conservação: uma Leitura sobre a Contribuição do Instituto Chico Mendes. Biodiversidade Brasileira, v. 4, n. 1, p. 211-234, 2013.

NOBRE, D.M.; SCHIAVETTI, A. Acordos de pesca, governança e conselho deliberativo de reserva extrativista: caso da RESEX de Cassurubá, Caravelas, Bahia, Brasil. Boletim do Instituto de Pesca, v. 39, n. 4, p. 445-455, 2013.

RAMOS, A. Políticas Públicas para áreas protegidas no Brasil. In: Bensusan, N.; Prates, A.P.A Diversidade cabe na Unidade? Áreas Protegidas no Brasil. IEB Mil Folhas. 2015.

ROWE, G., FREWER, L.J. Public participation methods: a framework for evaluation. Science, Technology and Human Values, 25: 3-29.2000.

SANTILLI, J. Socioambientalismo e novos direitos: Proteção jurídica à diversidade biológica e cultural. Editora Peirópolis, Instituto Socioambiental e Instituto Internacional de Educação do Brasil. 2005.

SEIXAS, C.S., VIEIRA, M.A.R.M. Fisher's knowledge and the Ecosystem Approach to Fisheries: legal instruments and lessons from five cases studies in coastal Brazil. In: Fischer, J. et al. (Eds.) Fishers' Knowledge and the Ecosystem Approach to Fisheries. Applications, Experiences and Lessons in Latin America. Fisheries and Aquaculture Technical Paper (FAO), n. 591. Roma. p 73-116. 2014.

STRINGER, L.C., A.J. DOUGILL, E. FRASER, K. HUBACEK, C. PRELL, D C. REED. Unpacking "participation" in the adaptive management of social-ecological systems: a critical review. Ecology and Society, 11(2):39. 2006.

TEIXEIRA, D. R. et al. Descrição e análise quantitativa da composição e grau de participação dos atores públicos e privados nos conselhos de unidades de conservação e mosaicos federais segundo o arcabouço legal. V Encontro da Associação Nacional de Pós-Graduação e Pesquisa em Ambiente e Sociedade, 2010.

TRIMBLE, M., ARAUJO, L.G. E SEIXAS, C.S. One party does not tango! Fishers' non-participation as a barrier to co-management in Paraty, Brazil. Ocean \& Coastal Management, 92: 9-18. 2014.

VAZ, A.C. Da participação à qualidade da deliberação em fóruns públicos: o itinerário da literatura sobre conselhos no Brasil. In: Pires, R.R.C. (org). Efetividade das Instituições Participativas no Brasil: Estratégias de Avaliação. Diálogos para o Desenvolvimento. v.7. Instituto de Pesquisa Econômica Aplicada - Ipea, 2011.

VIVACQUA, M.; RODRIGUES, H. de C. L. O Meu Lugar é do Outro: As Vozes dos Invisíveis nos Espaços Formais de Gestão Ambiental Participativa do Território Sul da APA da Baleia Franca. Anais do VI Encontro Nacional da Associação Nacional de Pós-Graduação e Pesquisa em Ambiente e Sociedade, 2012.

VON KORFF, Y., P. D'AQUINO, K.A. DANIELL, AND R. BIJLSMA. Designing participation processes for water management and beyond. Ecology and Society, 15(3):1. 2010. 


\section{Deborah Santos Prado}

$\square$ deborah.stprado@yahoo.com.br

ORCiD: https://orcid.org/0000-0002-4671-8507
Submitted on: $28 / 05 / 2018$

Accepted on: 23/04/2020

2020;23:e00362

\section{Luciana Gomes de Araujo}

๑lgaraujo21@usp.br

ORCiD: https://orcid.org/0000-0002-1760-2417

\section{Paula Chamy}

$\square$ paula.chamy@gmail.com

ORCiD: https:// https://orcid.org/0000-0002-3877-5544

\section{Ana Carolina Esteves Dias}

曰dias.ac09@gmail.com

ORCiD: https://orcid.org/0000-0001-6475-6227

\section{Cristiana Simão Seixas}

$\square$ csseixas@unicamp.br

ORCiD: https://orcid.org/0000-0002-4464-2094

How to cite: PRADO, D. S.; ARAUJO, L. G.; CHAMY, P. DIAS, A. C. E.; SEIXAS, C. S. Social Participation in Management Councils of Protected Areas: Normative advances and the perspective of ICMBio Environmental officers. Ambiente $\mathbb{\&}$ Sociedade. São Paulo, v. 23, p. 1-23, 2020. 


\title{
Participação Social nos Conselhos Gestores de Unidades de Conservação: Avanços normativos e a visão de agentes do ICMBio
}

\author{
Deborah Santos Prado \\ Luciana Gomes de Araujo \\ Paula Chamy \\ Ana Carolina Esteves Dias \\ Cristiana Simão Seixas
}

São Paulo. Vol. 23, 2020

Artigo Original
Resumo: Os Conselhos Gestores são considerados instrumentos de gestão inovadores e importantes ao exercício da democracia no campo socioambiental. Este artigo buscou integrar a evolução dos marcos regulatórios dos Conselhos Gestores de Unidades de Conservação e a visão de servidores envolvidos nos processos de formulação das normas, a fim de compreender a trajetória de negociação desses processos. Os resultados mostram que a participação social está formalmente garantida em diversos aspectos das normas analisadas, o que representa uma conquista para a gestão ambiental mais democrática e inclusiva de Unidades de Conservação. Ainda assim, foram identificados paradoxos e desafios, relativos a aspectos de representatividade, independência, influência e compartilhamento genuíno de poder em processos de tomada de decisões. Os resultados sociais da participação pressupõem processos contínuos de aprendizagem e negociação, que se refletem no aprimoramento dos arranjos jurídicos analisados.

Palavras-chave: Gestão Participativa; Representatividade; Legislação Ambiental; Conselho Consultivo; Conselho Deliberativo.

Como citar: PRADO, D. S.; ARAUJO, L. G.; CHAMY, P. DIAS, A. C. E.; SEIXAS, C. S. Participação Social nos Conselhos Gestores de Unidades de Conservação: Avanços normativos e a visão de agentes do ICMBio. Ambiente \& Sociedade. São Paulo, v. 23, p. 1-23, 2020. 


\title{
Participación social en los Consejos de Gestión de Áreas Protegidas: Avances normativos y la visión de los agentes ambientales de ICMBIO
}

\author{
Deborah Santos Prado \\ Luciana Gomes de Araujo \\ Paula Chamy \\ Ana Carolina Esteves Dias \\ Cristiana Simão Seixas
}

São Paulo. Vol. 23, 2020

Artículo original
Resumen: Los Consejos Gestores han sido considerados instrumentos institucionales de administración, que son innovadores al ejercicio de la democracia brasileña en el campo socio ambiental. Este artículo buscó integrar la evolución de los marcos regulatorios de los consejos gestores de áreas protegidas de Brasil y la visión de servidores involucrados en los procesos de formulación de las normas, a fin de comprender la trayectoria de negociación de esos procesos. Los resultados muestran que la participación social está formalmente garantizada en diversos aspectos de las normas analizadas, lo que debe considerarse una conquista para la gestión de áreas protegidas en Brasil. Sin embargo, se señalan algunas paradojas y desafíos, incluyendo cuestiones de representatividad, independencia, influencia y compartimentos genuinos de poder en la toma de decisiones. Los resultados sociales de la participación presuponen procesos continuos de aprendizaje y negociación, que se reflejan en el perfeccionamiento de los arreglos jurídicos analizados.

Palabras-clave: Gestión Participativa; Representatividad; Legislación Ambiental; Consejo Consultivo; Consejo Deliberativo.

Como citar: PRADO, D. S.; ARAUJO, L. G.; CHAMY, P. DIAS, A. C. E.; SEIXAS, C. S. Participación social en los Consejos de Gestión de Unidades de Conservación: Avances normativos y la visión de los agentes ambientales de ICMBIO. Ambiente $\mathbb{\&}$ Sociedade. São Paulo, v. 23, p. 1-23, 2020. 